\title{
QUALIFICAÇÃO PROFISSIONAL NA POLÍCIA MILITAR DO AMAPÁ: UM ESTUDO DE CASO
}

\section{ARTIGO ORIGINAL}

MENDONÇA, Luiz Tobias Rodrigues ${ }^{1}$

MENDONÇA, Luiz Tobias Rodrigues. Qualificação profissional na Polícia Militar do Amapá: Um estudo de caso. Revista Científica Multidisciplinar Núcleo do Conhecimento. Ano 05, Ed. 03, Vol. 07, pp. 93-118. Março de 2020. ISSN: 2448-0959, Link de acesso: https://www.nucleodoconhecimento.com.br/educacao/policia-militardo-amapa

\section{RESUMO}

O presente estudo de caso, pretende analisar o cenário da qualificação profissional no Centro de Formação e Aperfeiçoamento (CFA), objetivo Geral é analisar o planejamento pedagógico antes do Estatuto e depois, para avaliar a evolução no ensino da Instituição, o objetivo Específico pretende colher algumas informações que possam subsidiar essa análise dentro do processo ensino-aprendizagem realizados no CFA com a participação dos alunos dos Cursos de soldado e sargento do ano de 2019. Metodologia empregada foram documental, levantamento de dados, através de questionário com perguntas fechadas, usando o método exploratório quali-quant, com amostra de 623 (seiscentos e vinte e três) alunos, 230 (duzentos e trinta) do curso de sargento e 393 (trezentos e noventa e três) do curso de soldados do Universo de 3.175 policiais, com probabilidade de erro de $4 \%$ e confiabilidade de $99 \%$. A conclusão que a carga horária são elevadas de 1.309 (mil trezentos e nove) horas/a do curso de

${ }^{1}$ Doutor em Ciências Policiais de Segurança e Ordem Pública/Barro Branco/PMESP. Especialista em Gerenciamento de Segurança Pública e em Conhecimentos Jurídicos em Segurança Pública, Pós-graduação em Docência na Educação Superior/IESAP e Gestão Pública pela Universidade Estadual do Amapá, Graduado na Academia de Polícia Militar do Pau-d'alho/PE. 
soldado e 996 (novecentos e noventa e seis) horas/a do curso de sargento, com os conteúdos abordados são superficiais em alguns casos, com o uso inadequado da plataforma, que poderia ser melhor explorada, a falta de instrutores também prejudicam o processo de ensino, ainda utiliza-se uma abordagem inapropriada para o nível superior exigido, e os certificados ainda não reconhecidos pelo Ministério da Educação dos respectivos cursos.

Palavras-chave: Educação profissional, qualificação, formação, Policial Militar.

\section{INTRODUÇÃO}

A pesquisa versa sobre a qualificação profissional na Polícia Militar do Amapá, com base no Art. 21, inciso II "Ter instrumento que permitam visualizar as dificuldades dos alunos, com intuito de aprimorar o processo de Ensino-aprendizagem" orientado pela Portaria no 007/17/GAB CMDO GERAL, publicada no Boletim Geral no 029, de 09 de Fev.2017.

A pesquisa pretende analisar o cenário da qualificação profissional no Centro de Formação e Aperfeiçoamento (CFA) órgão responsável pela formação e capacitação dos policiais militar do Amapá para o exercício do Policiamento Ostensivo (PO) e na Preservação da Ordem Pública.

Portanto, o objetivo Geral é analisar o planejamento pedagógico (PP) do CFA, enquanto que o objetivo Específico pretende comparar com a Matriz Curricular Nacional (MCN) do Ministério da Justiça, através das disciplinas dos Cursos de soldado e sargento do ano de 2019.

A metodologia adotada um estudo de caso, com levantamento documental e de dados, com o método exploratório quali-quant, onde foi previamente solicitado a Diretoria de Ensino e Instrução (DEI) da Polícia Militar do Amapá (PMAP), através de um memo. no 686-DIP para aplicação de um questionário, com 09 (nove) perguntas fechadas realizado pelo aplicativo eletrônico survio[2] disponibilizado na plataforma EaD[3] utilizada nos cursos do CFA, a pesquisa apresenta uma margem de erro de 
4\% e uma confiabilidade de 99\%, com uma amostra de 623 (seiscentos e vinte e três) alunos dos quais 230 (duzentos e trinta) equivalente a $37 \%$ do curso de sargento e 393 (trezentos e noventa e três) do curso de soldado, equivalente a $63 \%$ de um Universo de 3.175.

Com direcionamento para os Cursos de Formação de Soldado e de Sargentos que responderam no prazo de 23 (vinte e três) dias, iniciando dia 28 de Novembro com término dia 20 de dezembro de 2019. A estrutura do artigo segue com uma breve introdução, o desenvolvimento discorre a evolução histórica da Polícia Militar do Amapá até os dias atuais, seguido de um subitem que trata-se da evolução da qualificação profissional na PMAP, depois outro item que traz uma reflexão das teorias da teorias educativas e as policias militares na contemporaneidade, depois a análise dos dados e finalizando com as considerações finais.

\section{DESENVOLVIMENTO}

\subsection{EVOLUÇÃO HISTÓRICA DA POLÍCIA MILITAR DO AMAPÁ ATÉ A OS DIAS ATUAIS}

Segundo professor Jeferson Gonzalez[4], em uma retrospectiva na história da educação no Brasil, até o século XIX, "não existia uma educação profissionalizante sistemática nesse período, só em 1809 com a criação dos colégios das fábricas que pode ser considerada como o início da educação profissional no Brasil”, naquela época a situação se caracterizava como assistencialista e predominantemente comercial, internacional, devida à agricultura, com o surgimento de várias Instituições privadas para atender as crianças pobres e órfãs, porém, direcionavam seus ensinos para os ofícios de sapataria, carpintaria, tornearia para formar trabalhadores.

Em 1930 no auge da urbanização no país, com o avanço da migração do campo para a cidade, a população começava a exigir moradia, saúde e educação, o acesso à educação era difícil, ofertava-se o ensino primário e o ginasial, curso superior era só pra elite, até 1940 a educação era marcada pela divisão de classe, um ensino conduzia a profissionalização e vedava ao ensino superior e outros para a formação 
propedêutica,[5] pois, desde da origem das divisões de classe que a educação se tornou dualista.

Portanto, com essa contextualização histórica que surgiu a Polícia Militar do Amapá, oriunda da Guarda Territorial (GT) do instinto Território do Amapá, criada através da Lei $n^{\circ}$ 5.839, de 21 de setembro de 1943. No início a Guarda tinha caráter civil, por isso, que mesclava-se a missão de segurança pública com a de construção civil, quando se refere a essa mistura foi devido a situação vivida na época da urbanização no país, subordinados a organização do Departamento de Segurança Pública e Guarda Territorial (DSPGT). Em 1975, através da lei oㅜ 6.270/75 que se instituíram as polícias Militares dos Territórios Federais do Amapá, Rondônia e Roraima (MENDONÇA, p. 568, 2017).

O ensino profissional na época da Guarda Territorial que originou-se a Polícia Militar do Amapá, a parte física, rusticidade, coragem eram exigidas dos voluntários, tinham que ser forte, saber defesa pessoal, devido a formação ser tipicamente militarizante, mais rígido que hoje, em relação a escolaridade precisavam do curso primário[6] sendo que na atualidade, alguns Estados chegaram até realizar vestibular para o curso de formação de oficial, exemplo da Polícia Militar de Pernambuco, isso antes do exame nacional do ensino médio (ENEM) entrar em vigor.

Recentemente, em 2018 o Governo do Estado realizou um concurso para ingressar na Polícia Militar do Amapá, que chegou a 14.445 (quatorze mil e quatrocentos e quarenta e cinco) escritos, uma média de 48 por vaga, ofertadas 300 (trezentas) vagas diretas e 900 reserva, com salário de $R \$ 3,700.00$ mil (três mil e setecentos)[7] toda essa concorrência devido a oportunidade de estabilidade econômica, e a dificuldade de conseguir uma emprego melhor, que possa proporcionar uma qualidade de vida melhor que a concorrência se tornou acirrada.

Apesar da Lei Complementar № 084, de 07 de Abril de 2014, que versa sobre o Estatuto dos Militares do Estado do Amapá em seu art. 10 inciso III, exigir que "no ato da matrícula em curso de formação de soldado, nível superior de estabelecimento de ensino reconhecido pelo Ministério da Educação" (MEC) a cada concurso a demanda 
aumenta, em 1991 foi apenas 600 (seiscentos) escritos pra 100, hoje nem se compara com a procura de 2018. Em virtude desse requisito que a pesquisa pretende trazer à tona a discussão da qualificação profissional no âmbito da polícia militar do Amapá.

\subsection{O PROCESSO DE QUALIFICAÇÃO PROFISSIONAL NA POLÍCIA MILITAR DO AMAPÁ}

A educação profissional na Polícia Militar do Amapá (PMAP) encontra-se embrionária, - Centro de Formação e Aperfeiçoamento (CFA) antes conhecido como Centro de Formação e Aperfeiçoamento de Praças (CFAP), criado em 1976, para qualificar apenas soldados, os instrutores, eram oficiais oriundos do Exército Brasileiro (EB), e outros oficiais formados no Estado de Sergipe, com auxílio dos sargentos formados em Goiás e Minas Gerais.

Em 1986, ganhou novas instalações saindo do Quartel do Comando Geral (QCG) para o atual instalação, passando a se chamar Centro de Formação e Aperfeiçoamento de Praças "CAP PM FRANCISCO CHAGAS DA SILVA" em homenagem a um Oficial da PMAP. (LIMA, 2014)

Conforme publicado no Boletim Geral no 147, de 13 de Agosto de 2018, em 1989 houve $01^{\circ}$ curso de soldados com homens e mulheres, onde formaram as primeiras policiais militares, no ano seguinte foi realizado o $1^{\circ}$ Curso de Sargentos, em de 1998, foi realizado o $1^{\circ}$ Curso de para serem nomeados ao posto de $2^{\circ}$ Ten Habilitação de Oficiais Administrativos (CHOA), habilitando Subtenentes do Quadro de Oficiais Administrativo (QOA) Quando comeram a realizar vários curso, mudaram para Centro de Formação e Aperfeiçoamento (CFA) .

Em dezembro de 2016, foram formados os primeiros oficiais do estado, um total de 56 (cinquenta e seis) Oficiais realizando no Amapá o primeiro Curso de Formação de Oficiais (CFO). Então, com todos os cursos agora sendo realizado no Estado, tendência é cada vez aprimorar o ensino embrionário na Instituição, apesar que em relação ao ensino técnico-profissional houve um avanço, enquanto que a parte de gestão, pelo fato dos cursos de oficiais serem realizados fora do Estado prejudicava 
os oficiais quando retornavam, pois, muitas disciplinas eram voltadas a realidade de cada ente.

Quando se refere ao ensino tecnicista, que cria um clima de desenvolvimento educacional profissional com visão fragmentada no processo com perspectiva dominante, se torna alienante, pois não domine o processo como todo, apenas, aperta os parafusos, mas não sabe o processo da peça inteira, seguindo a teoria fordista e taylorista, assim, o processo do ensino e aprendizagem com disciplinas isoladas.

Em virtude do $05^{\circ}$ Batalhão, conhecido como Batalhão de Operações Especiais (BOPE), criado, através, do Decreto Lei no. 6803, de 06 de dezembro de 2002, em que seus integrantes foram qualificados em diversas áreas, apesar da experiência em atividades de radiopatrulhamento[8], na extinta Companhia Independente de Radiopatrulha (CIRP), uma das mais antigas modalidade de policiamento Ostensivo.

A educação profissional das atividades de polícias, os quais muitas vezes vocacionados, devido as exigências físicas e psicológicas da vida castrense, em especial aos integrantes do Batalhão de Força Tática e do BOPE, que os conhecimentos desses policiais consistem, "em primeiro lugar, em habilidades, e que todo ser humano é um centro de percepções e agência em um campo de prática" que capacitaram-se nas diversas áreas (INGOLD. p. 7, 2009)

Essas habilidades foram em diversas modalidades de policiamento, exemplo do patrulhamento tático motorizado foi um grande avanço no aprimoramento das técnicas empregadas no policiamento, apenas com poucas diferenciações, em virtude das características peculiares de cada Unidade. Hoje, essa modalidade de policiamento, com o passar dos tempos foram se aprimorando, com novas técnicas e doutrinas reformuladas, mudança dos veículos, conhecido como viaturas (VTR), equipadas com características específicas, com grande poder de persuasão com 04 (quatro) policiais qualificados para enfrentar os diversos crimes de maior relevância, essas habilidades são executadas simultaneamente, cada policial com atribuições específicas. 
Outra modalidade de policiamento de choque, conhecido também como ações de controle de distúrbio Civis, que são empregado em revistas de estabelecimentos prisionais, requer um conhecimento dos equipamentos e armamentos não letais[9]. Além, dessas modalidades, existem outra, que exigem dos policiais, um condicionamento físico com facilidade em adaptar-se ao meio líquido, nas alturas, pois, são empregados em situação diversas, em quaisquer terrenos e circunstâncias, ainda realizam escolta de autoridades, atuam em situações com reféns, esses policiais são conhecidos em todas as polícias militares com jargão de caveiras, com um significado bastante valorizado entre as tropas especiais, pela sua representação como se vê:

Esse símbolo é mundialmente reconhecido como das tropas de operações especiais. A história desse símbolo remonta os anos de 1945 no final da segunda guerra mundial, quando as tropas alemãs estavam perdendo a guerra. $\mathrm{Na}$ ocasião existia uma tropa chamada "SS", a qual se reportava diretamente a Hitler, tendo em vista que ele era considerado o comandante em chefe daquela tropa nazista. A "SS" era uma tropa considerada pelos militares aliados como sendo carniceiros em termos de execução das ordens recebidas. No uniforme desses militares existia uma caveira como símbolo máximo de identificação, assim como em todo o bunker, para identificar o seu poder e establishment, também possuía uma caveira em um local de destaque que simbolizava a morte[10]

Por fim, não menos importante o policiamento que compõem de 05 (cinco) policiais para 04 (quatro) motos para suas atividades operativas, os quais requer técnicas para a condução das motocicletas aprimoradas ao extremo, situações que exige habilidades, destreza, devido ao risco, os cursos são conhecidos como "pilotagem de alto risco" conhecidos como Grupo de Intervenção Rápida Ostensiva (GIRO).

Dessa forma, que a Polícia Militar do Amapá avançou em policiamento diversos, os ensinamentos das técnicas empregadas são repassadas aos respectivos cursos de especializações, ou conhecimentos básicos, tanto pelos integrantes do BOPE quanto 
pela Força Tática, quando a disciplina é abordagem[11] está assume as aulas e tratando de outras disciplinas o 5ํㅡㄹ BPM toma a frente, devido o know-how, ambos gozam de prestígios junto à sociedade reconhecida pelos relevantes serviços prestados a sociedade Amapaense.

Do mesmo modo, que esses policiais militares buscaram conhecimentos, antes de serem policiais são seres humanos, por isso, estão sempre em interação com o meio que vivem, recebendo e exercendo influência do ambiente social (operacional) sempre se adaptando às normas e valores vigentes e aceitos por todos os integrantes, elevando sua autoestima e reconhecimento, isso que faz a diferença quando se participa de uma Unidade em que todos integrantes são motivados.

Nesses casos, os cursos de especializações que esses policiais participaram foi um marco histórico na Instituição que tinha simplesmente o objetivo de prepara-los para a vida operacional, o que contribuiu sobremaneira na formação de diversos cursos, que passaram pelo CFA, em relação as demais disciplinas das legislações, eram sempre ministradas por oficiais formados em academias fora do Estado, com o passar do tempo, quando foi exigido curso superior alguns graduados que eram formados nas Ciências Jurídicas foram assumindo esse papel, com essas competências advindas com a criação das unidades operacionais, foram inseridas na qualificação profissional dos cursos, segundo Mello e Turmena:

(...) modelo de competências migra do mundo do trabalho para o campo educacional, um exigindo do outro uma pessoa mais preparada para os novos desafios e o outro, verificando essas novas exigências. Muda 0 modelo da abordagem educacional para domínio de saberes (competência: saber teórico, o saber fazer, e o poder fazer), evidenciando estes saberes em conhecimentos, habilidades e atitudes. (MELLO, TURMENA, p. 95, 2011)

Portanto, essas habilidades em diversas técnicas são necessárias para o desempenho das funções dos policiais militares em seus cargos e funções dentro da Organização para melhor atender os anseios da sociedade, seguindo os princípios 
educacionais da flexibilidade, diversificação e transformação[12] que sempre estão aprimorando, exemplo da qualificação dos instrutores para desempenhar as atividade de magistério.

A Diretoria de Ensino e Instrução da Polícia Militar do Estado do Amapá, conforme edital oㅡ 011/2018-DEl/PMAP ficou à frente do certame para os cursos previstos no Anuário do exercício 2019. Durante essa capacitação de instrutores realizada no próprio CFA, para serem utilizadas nos cursos, realizados de maneira hibrida no processo ensino e aprendizagem, essa evolução na educação profissional da Instituição da PMAP.

\subsection{A QUALIFICAÇÃO NAS POLÍCIAS MILITARES NA CONTEMPORANEIDADE}

Quando se leva em conta a metáfora de Marcos Rolim, em seu livro a síndrome da Rainha vermelha, que fala sobre o policiamento e Segurança Pública no século XXI, alega ser um paradoxo a Segurança Pública, fazendo comparações com as organizações internacionais de Segurança Pública, que correm e não saem do lugar, pois, dependendo do prisma do seu olhar crítico, quando o foco é aprimoramento profissional as Instituições estão a quilômetros à frente em comparação a outros Estados da Federação, exemplo da Polícia do Estado de São Paulo em relação aos cursos que vão desde a graduação até o doutorado, desde 1983, enquanto que a Polícia Militar do Amapá, ainda não tem nenhum curso reconhecido pelo MEC, mas estão a caminhando, o importante não é marca passo, e sim, dar os primeiros passos, segundo Farias:

Bayley (1985/2001), Brodeur (2002) e Balestrieri (2003) também mencionam a preocupação das instituições policiais sobre temas de seu interesse como a própria reforma da polícia, desenvolvida inclusive pelos seus próprios componentes, do que se depreende que são as próprias instituições policiais que, até recentemente, tiveram a preocupação de pesquisar sobre a sua realidade social e profissional. Em seus cursos policiais militares, os oficiais alunos elaboram monografias como 
requisito parcial à conclusão de seus respectivos cursos, sendo que esse tipo de produção de conhecimento, que no Estado de São Paulo se iniciou no ano de 1983, vem buscando ajustar-se ao rigor científico universitário. (FARIA, p.7, 2011)

Segundo Farias (2011), cada vez mais, as Instituições estão se aprimorando no campo do conhecimento na área da Segurança Pública, algumas estão bem avançadas, enquanto outras se esforçam em sair das "competências migrando do mundo do trabalho para o campo educacional", como foi a evolução da Educação profissionalizante da PMAP. Pois, "cabe aos profissionais do ensino, em geral, uma parcela expressiva da responsabilidade de realização de tais transações, e para tanto suas competências devem estar alinhadas com as demandas da sociedade moderna" Perrenoud (1999 apud MELLO, TURMENA, p.91,2018),

Para tratar um assunto especifico, deve-se conceituar conforme sua previsão legal a Lei de Diretrizes e Bases da Educação Nacional (LDB), diz que "a educação profissional será desenvolvida em articulação com o ensino regular ou por diferentes estratégias de educação continuada, em instituições especializadas ou no ambiente de trabalho". Ensino profissional é o processo educativo que implica, além de uma formação geral, estudo de caráter técnico e a aquisição de conhecimento e aptidões práticas relativas ao exercício de certas profissões, segundo UNESCO (apud 2001 MENEZES, SANTOS, 2019)

Assim, a Matriz Curricular Nacional (MCN) do Ministério da Justiça, em que a Secretária Nacional de Segurança Pública, desde do ano de 2003 com um seminário nacional para tratar as questões da formação dos agentes de Segurança Pública do sistema único de segurança pública, depois em 2005 houve uma revisão incluíram matriz pedagógica, em 2012 houve a consolidação da MCN que incluíram o perfil profissiográfico, malha curricular que orienta a formação dos profissionais, carga horária recomendada para as disciplinas, sugestões bibliográficas (MCN, p.12,2014).

Através, desses anos de profissionalização com diversas "abordagem educacional para domínio de saberes (competência: saber teórico, o saber fazer, e o poder fazer), 
evidenciando estes saberes em conhecimentos, habilidades e atitudes". (MELLO, TURMENA, p.95, 2018); conhecer as Policiais, suas essências são poucas conhecidas, apenas as suas ações na sociedade que corriqueiramente são noticiadas.

A polícia é geralmente pouco conhecida. Poucos se dignam de estudála, embora sejam raros os que não se achem nela o que criticar, com fundamento ou sem ele. $\mathrm{O}$ fenômeno é praticamente universal, embora noutros países já se tenham feito estudos aprofundados e objetivo em torno do trabalho policial, para determinar-lhes, sobretudo, as deficiências e necessidades. A própria bibliografia sobre temas policiais é escassa, mormente quando se trata de enfoques mais gerais sobre 0 problema com que se defrontam a organização e seus integrantes. Limita-se mesmo a alguns livros de texto, especialmente em nosso país, para uso restrito nas escolas de formação profissional, estas também recentes. BAUER (1975 apud FARIA, p.3, 2011)

Portanto, que a pesquisa foi realizada para traçar um diagnóstico da qualificação profissional, realizada pelo Centro de Formação e Aperfeiçoamento da Polícia Militar do Amapá, a fim de trazer à tona a importância de reavaliação do planejamento pedagógico empregado atualmente para que um futuro próximo os cursos realizados pelo CFA sejam devidamente reconhecidos, que possam construir conhecimentos, com um rigor cientifico, com debates, painéis, fórum dentre outras ferramentas pedagógicas, para melhor qualificação, Segundo Goldstein as policias são comparadas com os médicos e o crime com as doenças, só que:

(...) no campo médico, a relação é muito mais específica: as doenças têm sido classificadas, os fatores que as causam têm sido isolados, programas preventivos têm sido desenvolvidos e testados, e a real capacidade do pessoal médico em prevenir e controlar males específicos tem sido demonstrada. Em contraste, no que toca à polícia e à comunidade, muito do que se fala em relação à criminalidade permanece em um nível muito geral, apesar de, como expressão, "crime" não ser mais significativo do que "doença". O problema é agravado porque a 
palavra é utilizada livremente - seja por políticos, pelos policiais e pela população em geral - como se tivesse um significado uniforme. Goldstein (2003 apud ROLIM, p. 23, 2006)

Essa metáfora, fica clara ao entendimento do leigos, quando aborda a celeuma da criminalidade, não é uma ação exclusiva de polícia, "é um erro culpar a polícia pela expansão do crime, quando deve ser atacado sempre e principalmente nas suas origens, este é o papel do Estado em acertar ou não na formulação e implementação de políticas públicas" (LAZZARINI, 1991, p.30). É um equívoco pensar que só as policiais são responsáveis, apesar que a Constituição Federal de 1988, em seu artigo 144 relaciona as Instituições de Segurança em que a Polícia Militar é responsável pelo Policiamento Ostensivo fardado, a Preservação da Ordem Pública[13].

Esse câncer que destrói a sociedade, a prevenção se deve a sociedade, pois não seguem as orientações, pois as (causas) são multifatoriais, não conseguem isola-las, por ser tratar de fatores sociais, depende de várias especialidades para acompanhalas, precocemente, "para existir esse tipo de problema, há fatores familiares, sociais e econômicos que são determinantes em um diagnóstico precoce para a prevenção" segundo PÓLVARA (1986, apud BENAVENTE, 2002, p.642).

Com certeza, quando essas doenças sociais saem do controle, a única solução é recorrer aos médicos da segurança pública. É por isso, que hoje os cursos de especializações são em sua maioria operacionais, para combater os efeitos da criminalidade como a panaceia para conter essas doenças sociais.

Pois, o Estado sem investimento na prevenção primária[14] adequadamente, a sociedade tende a adoecer, esse paradoxo é outra visão do mesmo prima da Segurança Pública, em relação a visão de Marcos Rolim, citado no início do capítulo, aqui, o Poder Público, por omissão de algumas políticas públicas de prevenções, sobrecarregam o SUS da Segurança Pública, as policiais militares do Brasil.

Por outro lado, as Instituições como a "Academia de Polícia Militar (APM) de Minas Gerais, demostram competência em sua gestão integrando ao Sistema Estadual de 
Educação, nos termos do Decreto Estadual s/no, de 29/11/2005, publicado no Diário Oficial de 30/11/2005". Conforme Edital de credenciamento de docentes $n^{\circ}$ 01/2013APM, conhecido como Curso superior de tecnologia em execução de polícia ostensiva (CSTEPO), deixando claro que, apesar das dificuldades existentes no campo político e social, a buscar na qualificação profissional em prol do bem comum da sociedade brasileira superam com esses percalços.

Em relação a matriz dos cursos de soldados da Polícia Militar do Amapá e a Matriz Nacional, observa-se algumas discrepâncias, vejamos:

As áreas temáticas propostas pela Matriz Curricular Nacional são: Sistemas, Instituições e Gestão Integrada em Segurança Pública; Violência, Crime e Controle Social; Conhecimentos Jurídicos; Modalidades de Gestão de Conflitos e Eventos Críticos; Valorização Profissional e Saúde do Trabalhador; Comunicação, Informação e Tecnologias em Segurança Pública; Cultura, Cotidiano e Prática Reflexiva; Funções, Técnicas e Procedimentos em Segurança Pública. (PASSOS ET AL, p.45, 2014)

Em relação as 08 (oito) áreas temáticas da $\mathrm{MCN}$, que trata-se de sistemas, Instituições e Gestão Integrada em Segurança Pública, o planejamento de ensino do CFSD, constatou apenas uma disciplina de Noções sistema de Segurança Pública e outra de policiamento Comunitário das 14(quatorze) temáticas.

Do mesmo modo, a área de Violência, crime e controle social dos 18(dezoitos) temas, apenas noções de criminologia aplicada consta no planejamento, na área do conhecimento jurídico, constatou várias disciplinas, na modalidade de Gestão de Conflito e eventos críticos, das 11(onze) disciplinas, apenas duas fazem parte do planejamento de ensino, prevenção e mediação de conflito.

$\mathrm{Na}$ área de valorização profissional e saúde do trabalhador, das 06(seis) disciplinas, só condicionamento físico teoria e prática, na área de comunicação e informação e tecnologia em Segurança Pública, das dez disciplina, 04(quatro) constam no 
planejamento do CFSD. Na área da Cultura, cotidiano e práticas reflexivas, das 10(dez) disciplinas, apenas duas e uma terceira e terceira é ordem unida, que não é prevista, e por último, técnicas e procedimentos em Segurança Pública, das 12 (doze) disciplinas, uma delas é técnicas para ações táticas, onde envolvem alguns procedimentos operacionais padrão (POP) como: abordagem, defesa pessoal, uso da força, técnicas de patrulhamento, o que não consta no planejamento de ensino do CFSD, é local de crime que é previsto.

Por fim, o que se analisou que algumas disciplinas que deveriam constar no planejamento não aparece. Portanto, conforme os dados abaixo pode ser revisto essa grade curricular do CFSD, bem como, ao CFS as matérias apresentadas são na sua maioria similar com a do curso de soldado, apenas algumas disciplinas diferenciadas, e que em relação a atribuição do cargo é totalmente diferenciada, em relação a carga horária do curso de sargento é de 996 (novecentos e noventa e seis) horas/a, enquanto a do curso de soldado de 1.309 (mil trezentos e nove) horas/a incluindo o estágio operacional de selva, portanto, veremos abaixo, que essa carga horária dá pra ser reduzida equalizando com outras disciplinas para melhor apresenta uma readequação do planejamento de ensino.

Segundo a Resolução ํo 003/2011- Comando Geral, publicado no Boletim Geral no 058, de 29 de março de 2011, diz o seguinte:

O Comandante Geral da Polícia Militar do Amapá aprova, manda pôr em execução e autoriza a divulgação na rede Intranet e a impressão, inclusive anexo ao Boletim Geral PM, do Regimento Interno da Diretoria de Ensino e Instrução da Polícia Militar do Amapá - 1르 Edição.

Art. 1 - A Diretoria de Ensino e Instrução, órgão técnico-normativo de direção do Comando Geral da Polícia Militar, voltado para o desenvolvimento do Ensino e Pesquisa, tem por finalidade planejar, coordenar, controlar e supervisionar a condução da educação e a avaliação do processo ensino-aprendizagem. 


\section{$(\ldots)$}

V - Planejar, fiscalizar, coordenar e controlar as atividades de formação, graduação, pós-graduação, habilitação e treinamento de policiais militares;

\section{$(\ldots)$}

Assim, é evidente que a Diretoria de Ensino e Instrução (DEI) que legalmente detêm a competência legal administrativa para estruturar os programas dos cursos da Instituição, planejar, coordenar o ensino na Polícia Militar do Amapá, o que casou estranheza que o Comandante do CFA, que confeccionou o planejamento de ensino dos cursos de soldado e sargento 2019. Pois, o CFA é considerado um órgão de execução como consta na redistribuição do Quadro de distribuição de efetivo (QDE) da Polícia Militar do Amapá, publicado no Decreto Governamental no 4048 de 26 de outubro de 2017. Nesse caso, se for por delegação nada óbice.

\section{RESULTADOS E DISCUSSÃO}

Para colher os dados para subsidiar a pesquisa, foi elaborado um questionário, contendo 09 (nove) perguntas básicas, para diagnosticar o processo ensinoaprendizagem do CFA, da Polícia Militar do Amapá, obtendo as seguintes respostas, seguem de acordo com a sequência das perguntas, sendo a primeira foi qual sua formação acadêmica, seguindo das demais, conforme os gráficos que seguem: 
Gráfico 1 - Qual sua formação acadêmica?

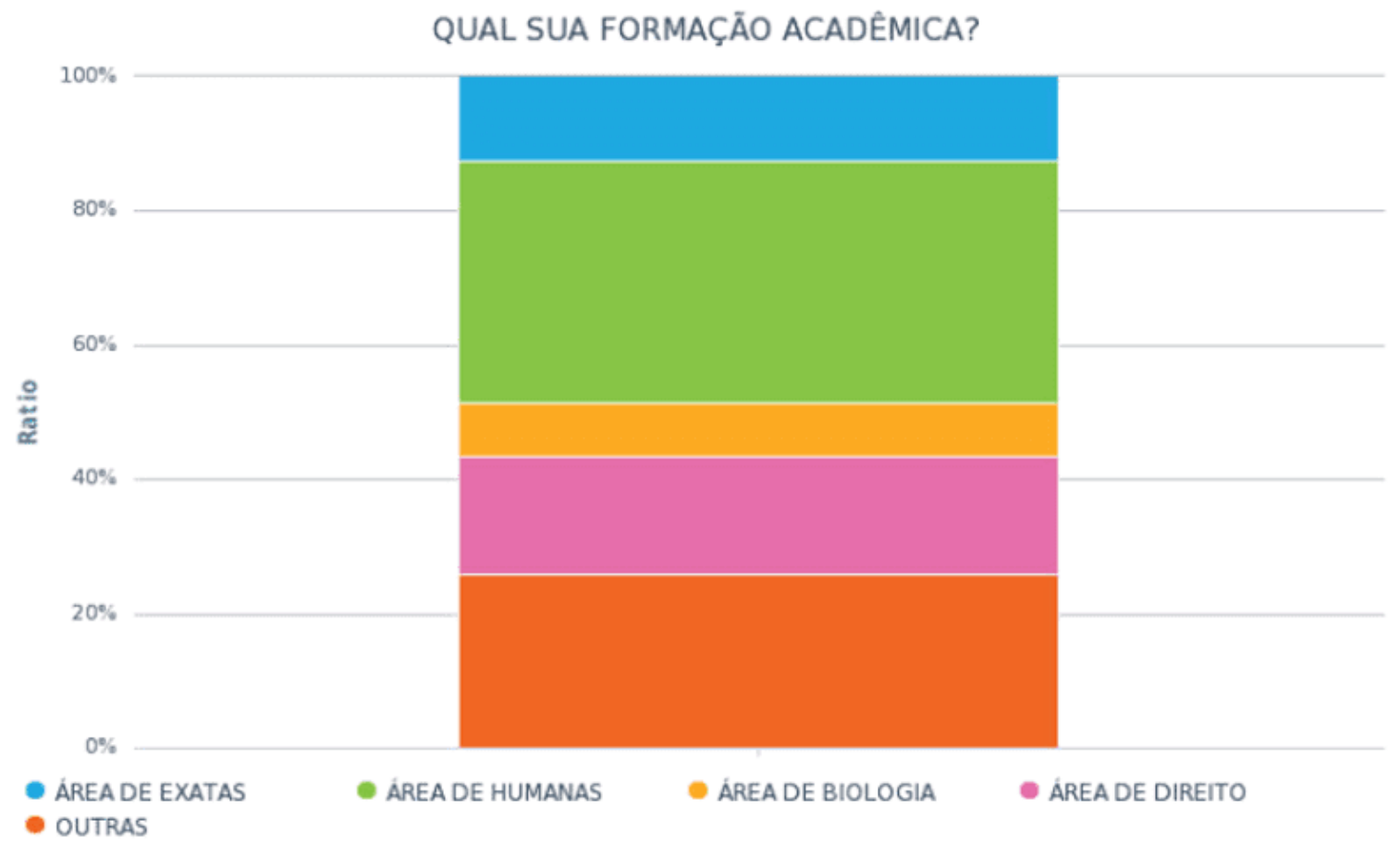

Fonte: Do autor

De acordo com a amostra de 622 (seiscentos e vinte e dois) alunos entrevistados, os resultados ficaram na seguinte proporção, $36,1 \%$ com formação no campo das ciências humanas, 25,8\% com formação em outras áreas, 12,5\% formados em ciências exatas, 17,5\% na área jurídica e 8\% em biologia. Então, 225 (duzentos e vinte e cinco) alunos têm sua formação acadêmica nas ciências humanas, em outras áreas do conhecimento 161 (cento e sessenta e um) e nas ciências exatas 78 (setenta e oito) alunos, no campo jurídico 109 (cento e nove) e na área das ciências biológicas apenas 50 (cinquenta).

Da análise se fosse pra escolher por afinidade, os alunos que fossem formados na área de exatas, seriam indicados para trabalharem nas Diretorias de Orçamento e Finanças, folha de pagamento, os alunos de biologia no Batalhão Ambiental, os da área jurídicas, corregedorias. 
A Instituição poderia aproveita os policiais que queiram exercer suas competências dentro da própria Instituição. Porém, alguns preferem fazer o que policiamento em uma escala de $12 \times 24 \times 12 \times 72[15]$ e garantir sua folga de até três dias, ao em vez, de trabalhar o expediente todos os dias.

A segunda pergunta se sua formação acadêmica contribui para a área da segurança pública, obtivemos a seguinte resposta, conforme gráfico 2 .

Gráfico 2 - Sua formação acadêmica pode contribuir com a área da Segurança Pública?

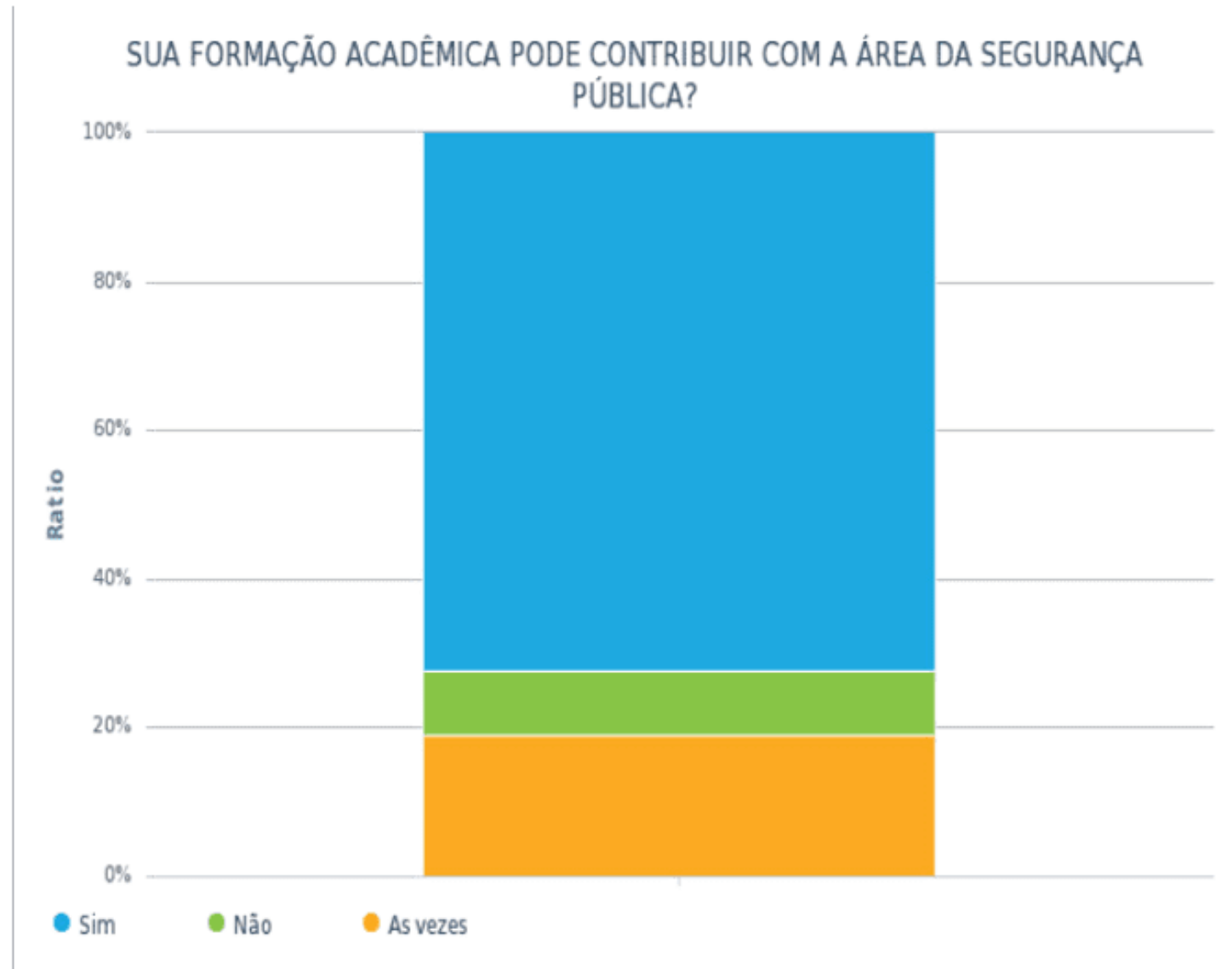

Fonte: Do autor

Nessa segunda pergunta a maioria, $72,4 \%$, ou seja, 451(quatrocentos e cinquenta e um) alunos afirmaram que sua formação acadêmica poderiam contribuir com a área da Segurança Pública, 18,9\% poderiam contribuir algumas vezes, ou seja 119 (cento e dezoito) alunos, e 54(cinquenta e quatro) alunos equivalente a $8,7 \%$ responderam 
que suas formações não contribuem para a Segurança Pública. Portanto, esses alunos, não devem conhecer ainda a dinâmica da Instituição e sua estrutura organizacional.

A terceira pergunta foi em relação a falta de professores durante as aulas com qual frequência, as respostas conforme gráfico 3 foram as seguintes:

Gráfico 3 - Durante o curso já ficaram sem aulas em razão da falta do instrutor? Com qual frequência mensal?

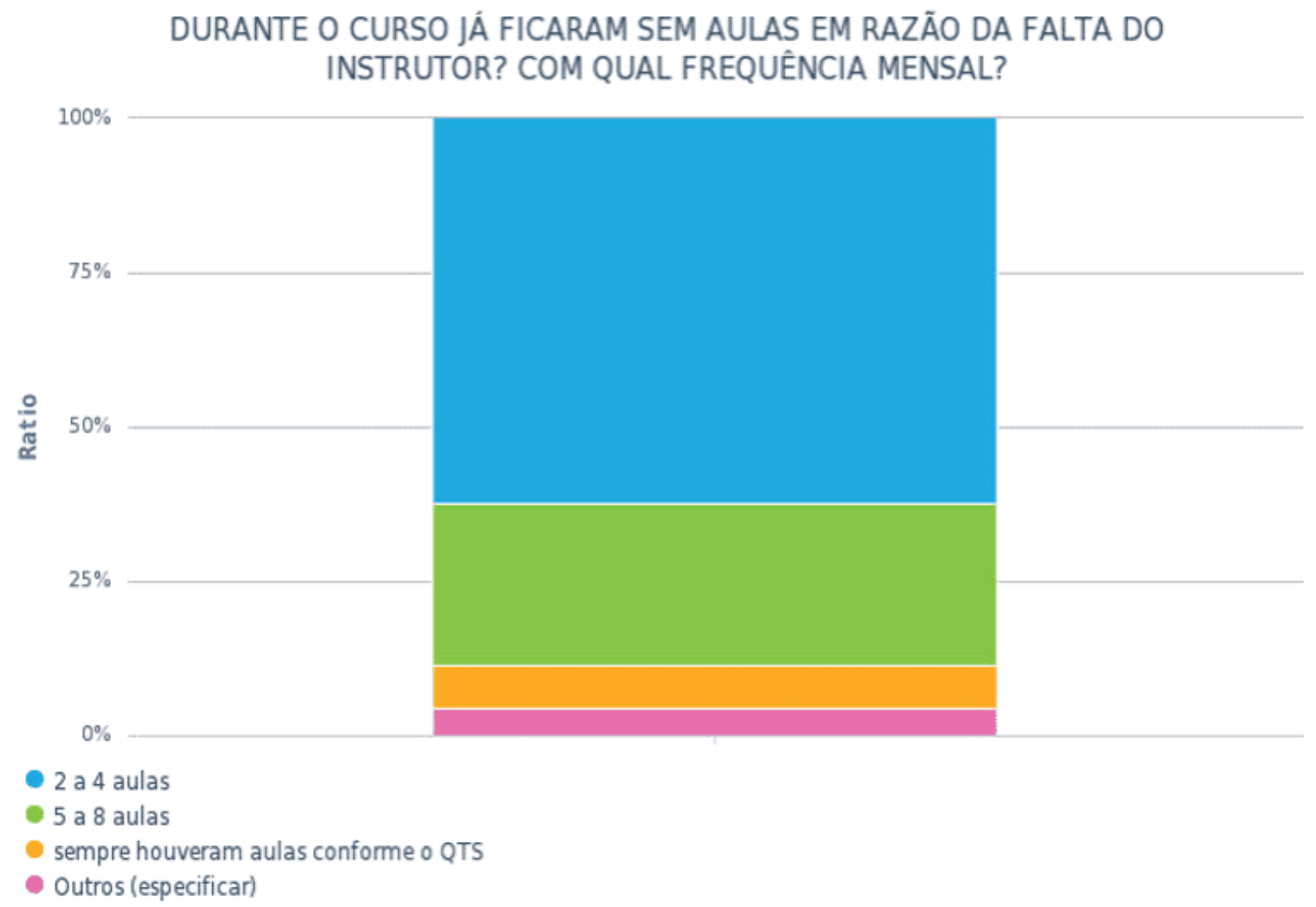

Fonte: Do autor

Nessa pergunta observa-se que a uma falha no processo ensino-aprendizagem, $62,3 \%$ equivalente a 388 (trezentos e oitenta e oito) alunos afirmaram que já ficaram sem aula pelo menos de 02 a 04 aulas, 26,2\% equivalente a 163 (cento e sessenta e três) afirmaram que ficaram sem aulas acima de 05 a 08 aulas, 6,9\% afirmaram que sempre tiveram todas as aulas conforme o Quadro de Trabalho Semanal (QTS) foram 
44(quarenta e quatro) alunos, os demais os $4,5 \%$ responderam outros, somam 28(vinte e oito) alunos que justificaram usando diversos argumentos, inclusive uma das respostas foi que o instrutor compareceu nas aulas, porém, não tinham didática, outra que o instrutor estava em missão, ou seja, estava de serviço. Então, que vê que na maioria das vezes os alunos ficam sem instrução por vários motivos, isso, implica na falta de planejamento para que os instrutores possam estar nas aulas para que não prejudique os alunos.

O quarto questionamento foi se algumas disciplinas de conhecimento gerais poderiam ser substituídas por outras de cunho específico na área da segurança pública, as respostas ficaram da seguinte forma, conforme gráfico 4 como podemos ver:

Gráfico 4 - Algumas disciplinas de conhecimentos Gerais poderiam ser substituídas por disciplinas específicas da área de Segurança Pública?

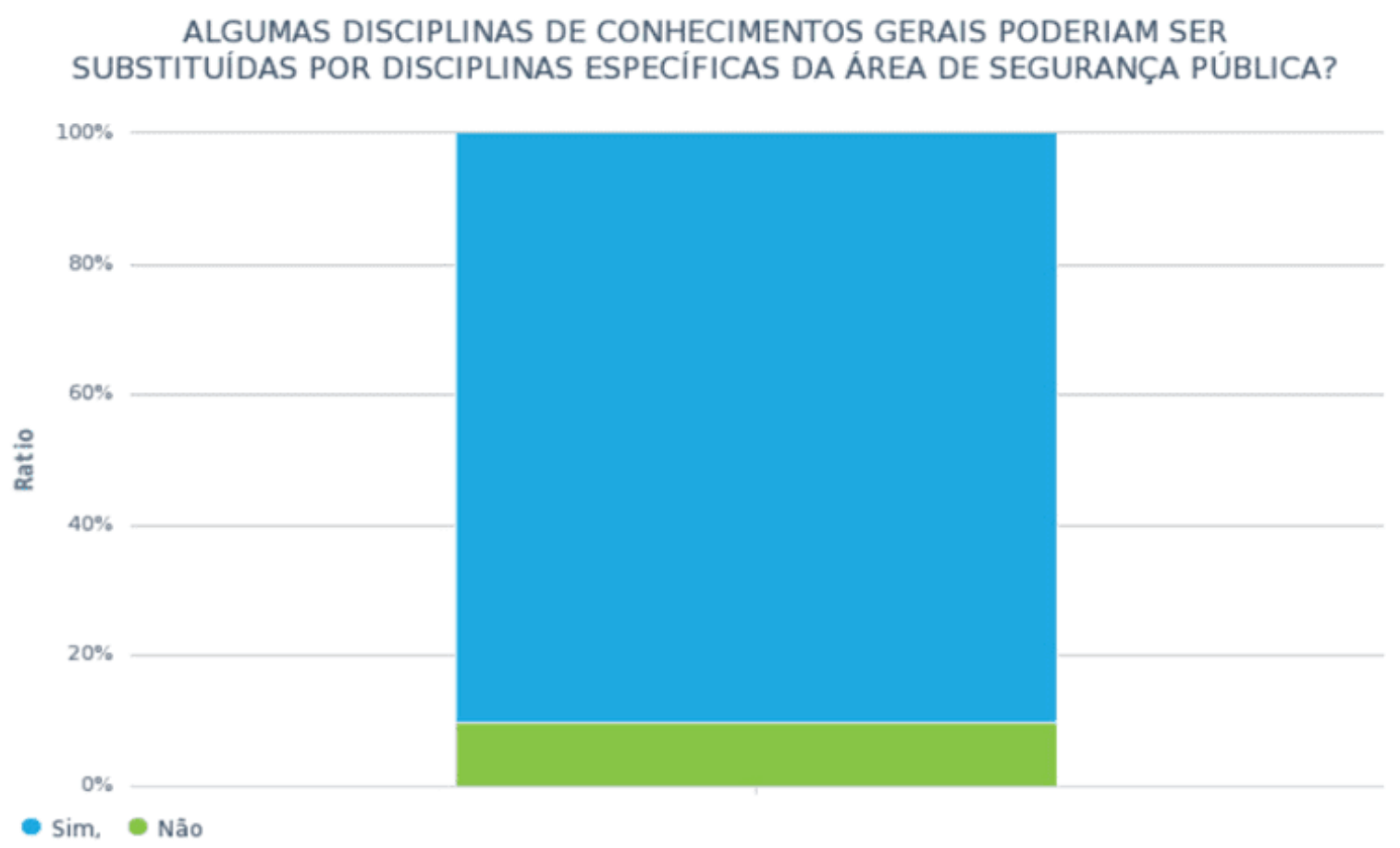

Fonte: Do autor

Nesse caso, 90,2\% equivale a 561 (quinhentos e sessenta e um) alunos gostariam que as disciplinas de conhecimento gerais poderiam ser substituídas por outras da área da Segurança Pública e apenas 9,8\% responderam que não, ou seja, apenas 61 
alunos querem que permaneçam as disciplinas de conhecimentos Gerais. Neste caso, a grande maioria queriam aprender outra disciplinas do campo da segurança Pública, demostram interesse de conhecer melhor de sua profissão.

No quinto questionamento que foi destinado a carga horária, ficou os resultados da seguinte forma, conforme gráfico 5 .

Gráfico 5 - Você acha que a carga horária do seu curso é suficiente pra sua Formação?

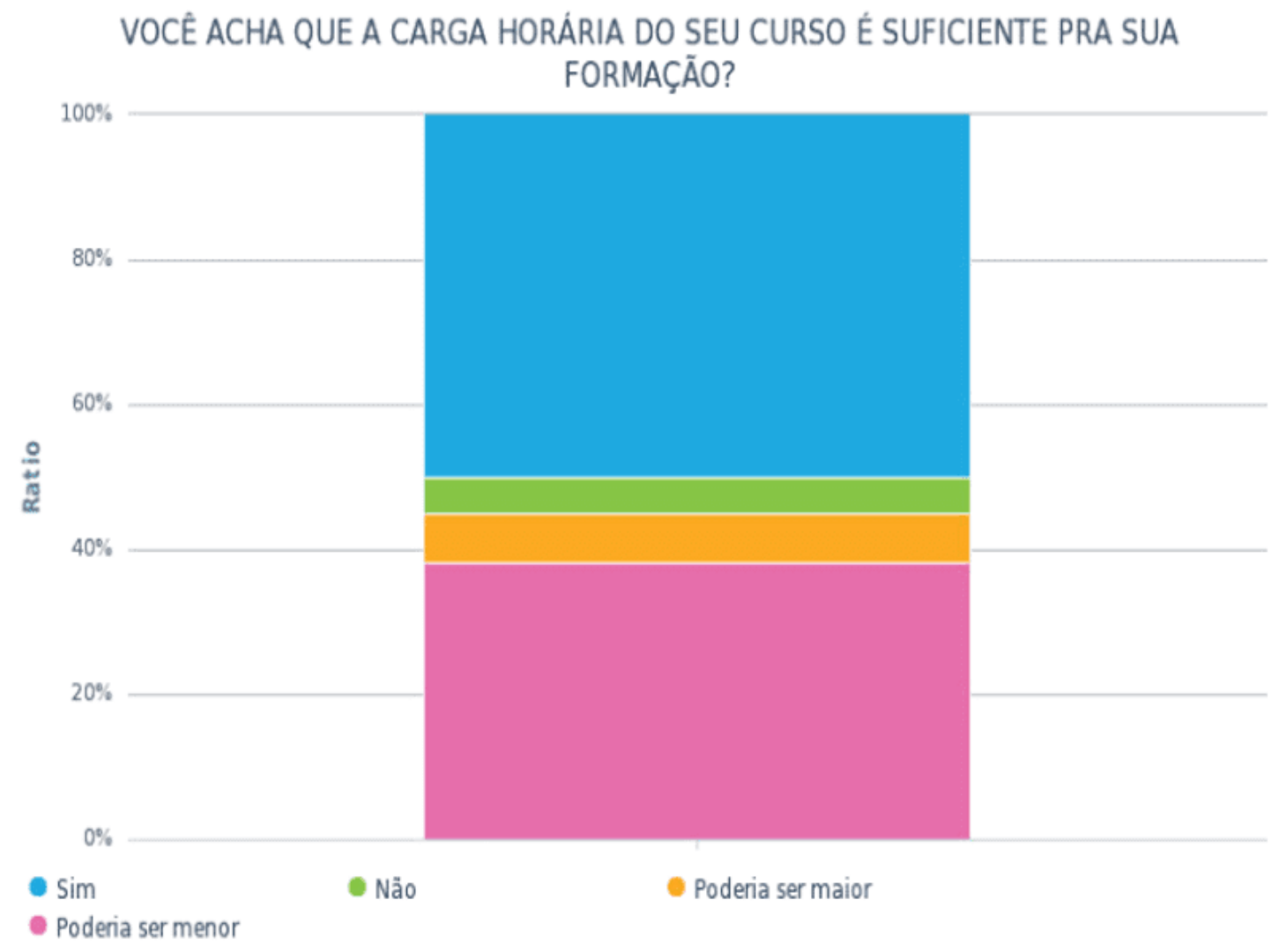

Fonte: Do autor

Em relação a carga horária, $50 \%$ afirmaram que o período de curso é suficiente, equivale a 311 (trezentos e onze) e $38,3 \%$ acham que poderia ser reduzida, equivale a 238 (duzentos e trinta e oito) alunos, 6,8\% acham que poderia aumentar, equivale a 43(quarenta e três) e 5\% que equivale a 31(trinta e um) alunos acham que não é suficiente a carga horária para a formação. 
Analisando as respostas a carga horária que é de 720 (setecentos e vinte) horas-aulas para a formação do curso de soldado, poderia ser reduzida com a substituição das disciplinas de conhecimento gerais por outras da área técnica, com o uso sistemático da plataforma $\mathrm{EaD}$ do CFA, com um método híbrido, com tutores qualificados, se tornaria exequível a redução do período de formação dos cursos em geral.

Em relação ao sexto questionamento em relação as disciplinas que poderiam ser ofertadas na plataforma EaD, ficou com os seguintes resultados, conforme gráfico 6

Gráfico 6- Quantas disciplinas poderiam ser ofertadas com carga horária integral na plataforma do CFA?

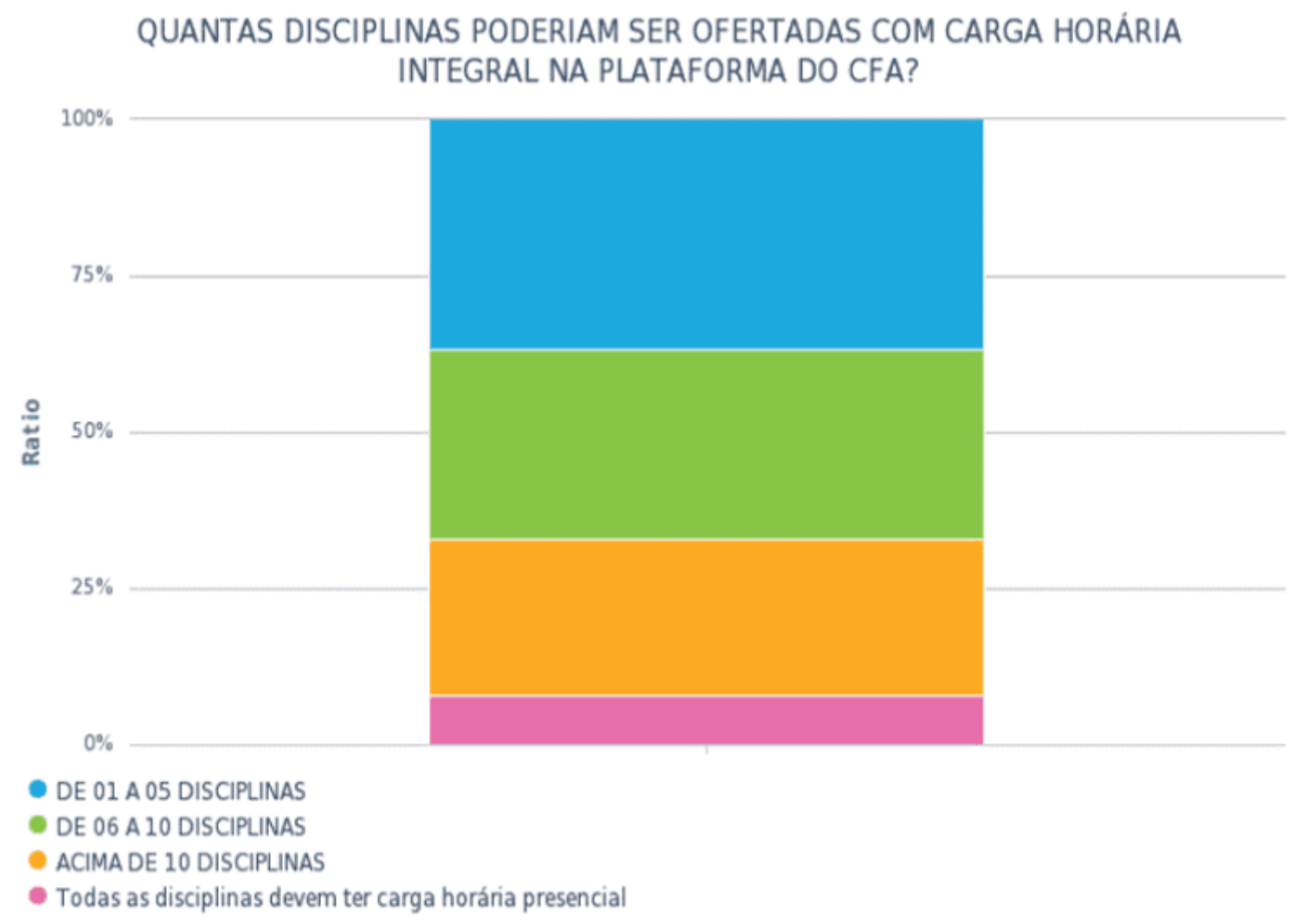

Fonte: Do autor

Dos resultados, 36,8\% afirmaram que de 01 a 05 disciplinas poderiam ser ensinadas pela plataforma, equivale a 229 (duzentos e vinte e nove) alunos, 30,4\% afirmaram de 06 a 10 disciplinas que poderiam ser utilizadas na plataforma do CFA, equivale a 189 
(cento e oitenta e nove), acima de 10 disciplinas foram 24,9\% equivale a 156 (cento e cinquenta e seis) apenas 7,9\% preferem que todas sejam presenciais, ou seja 49 alunos, então $92,1 \%$ são a favor que uma média de $10(\mathrm{dez})$ disciplinas podem ser substituídas do método presencial para a plataforma, podendo com isso, ser um fator favorável para a redução das horas-aulas dos cursos realizados no CFA.

Outro questionamento em relação ao horário dos cursos realizados no CFA, ficou da seguinte forma, com a maioria gostaria de ser dois turnos, conforme gráfico 7

Gráfico 7 - Qual o horário ideal para os cursos no CF?

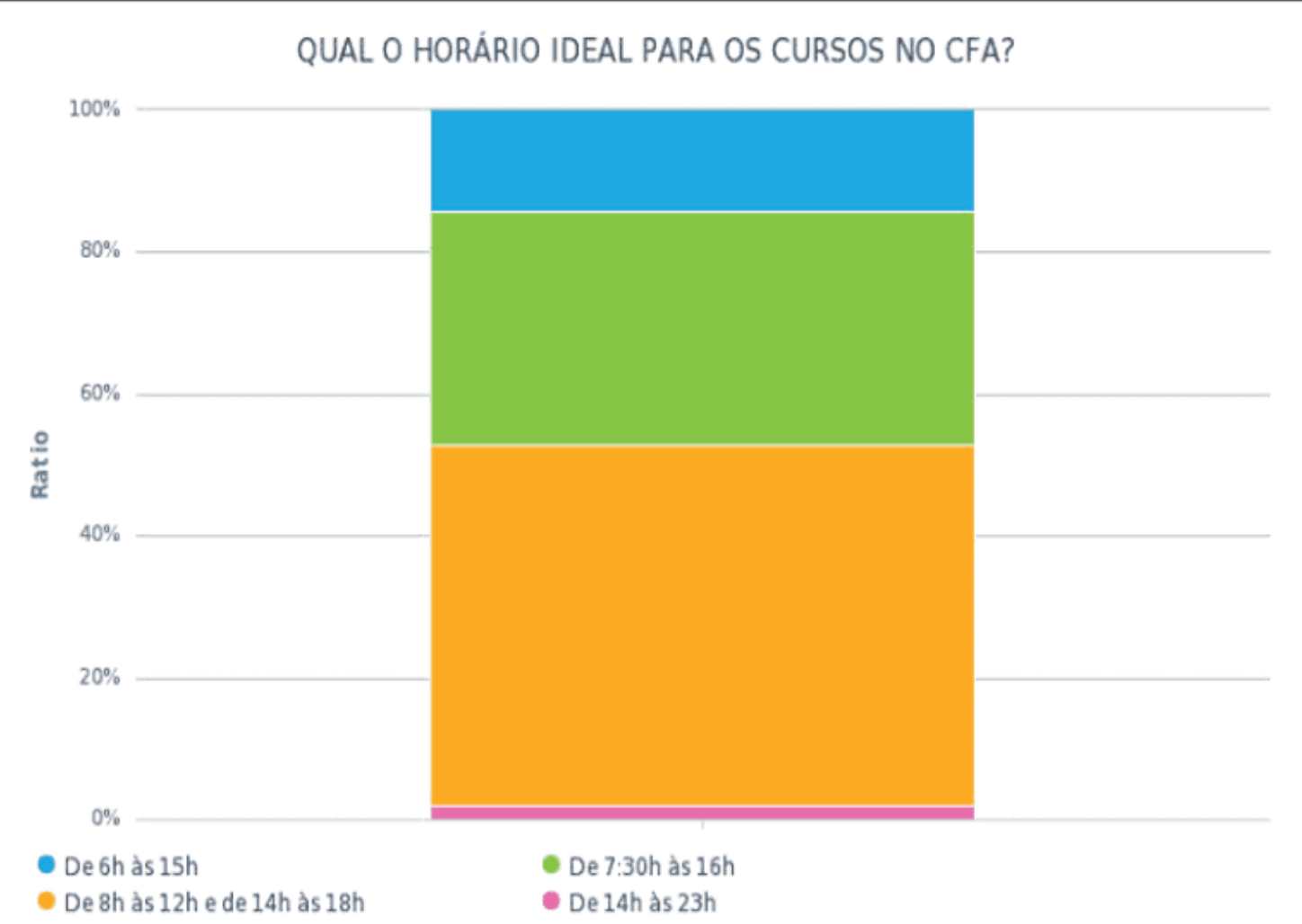

Fonte: Do autor

Das respostas em relação ao horário mais da metade dos pesquisados preferem os dois turnos, de $8 \mathrm{~h}$ as $12 \mathrm{~h}$ e das $14 \mathrm{~h}$ às $18 \mathrm{~h}$, chegou a $50,7 \%$ equivale 316 (trezentos e dezesseis) alunos, enquanto que das 7:30h as $16 \mathrm{~h}$ foram $33,2 \%$, equivale a 206 (duzentos e seis), do horário das $6: 00 \mathrm{~h}$ as $15: 00 \mathrm{~h}$ chegou a $14,2 \%$ equivale a 88 (oitenta e oito) alunos e uma minoria preferiam das $14: 00 \mathrm{~h}$ as $23: 00 \mathrm{~h}$, com $1,9 \%$ 
corresponde a 12 (doze) alunos. Então, pouco mais da metade preferiam que os cursos fossem em dois turnos, em segundo lugar foi o horário da 7:30 às 16:00h, o que pode ser feito uma enquete na Instituição com esses dois horários.

Em relação a oitava pergunta que envolve a disciplina de abordagem, que na sua grande maioria, optou para aprender na prática nas Unidades Operacionais, as respostas ficaram da seguinte forma, conforme gráfico 8

Gráfico 8 - Em relação a disciplina de abordagem seria melhor aprender na prática como estagiário nas unidades operacionais?

\section{EM RELAÇÃO A DISCIPLINA DE ABORDAGEM SERIA MELHOR APRENDER NA PRÁTICA COMO ESTAGIÁRIO NAS UNIDADES OPERACIONAIS?}

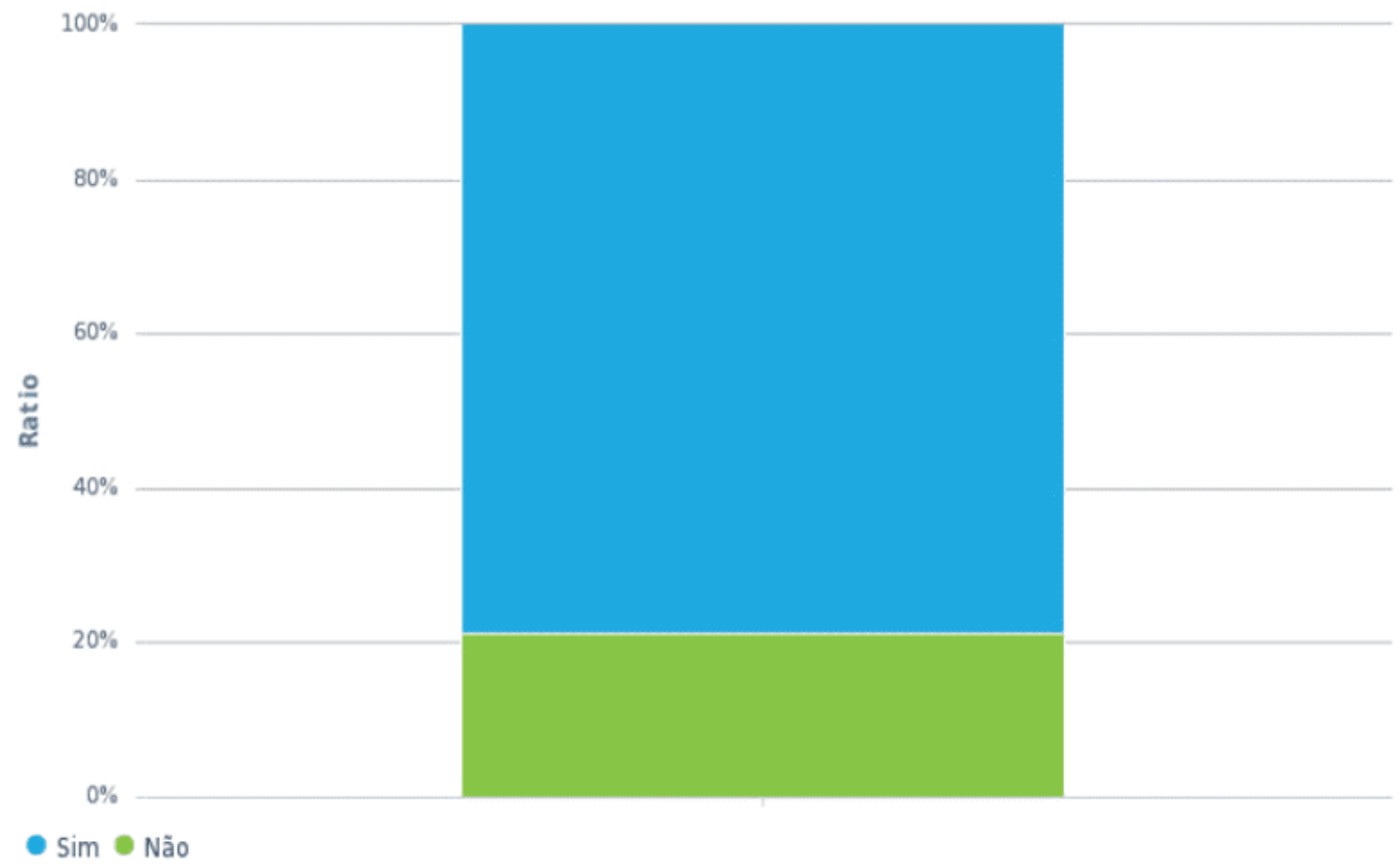

Fonte: Do autor

Em relação a repostas do interesse em aprender a disciplina abordagem nas Unidades Operacionais, $78,6 \%$ são a favor, equivale a 490 (quatrocentos e noventa) e apenas $21,4 \%$ que equivale a 133 (cento e trinta e três) são contrários a aprendizagem como estágios nos batalhões. Na sua maioria prefeririam aprender nos batalhões como estagiários, sendo favorável a vivência desses alunos no ambiente e 
situações reais, que vão enfrentar na sua profissão, após a conclusão dos cursos, principalmente os alunos do curso de soldados, que não detém experiências policiais.

Por último, a nona pergunta foi em relação a vontade de exercer suas atividades em qual Unidade, ficou dividido em relação aos alunos do curso de sargento que são oriundos de Batalhão e naturalmente retornariam, então, ficou para os alunos do curso de soldados responder essa última pergunta.

Gráfico 9 - Após a conclusão do curso em qual unidade você pretende trabalhar?

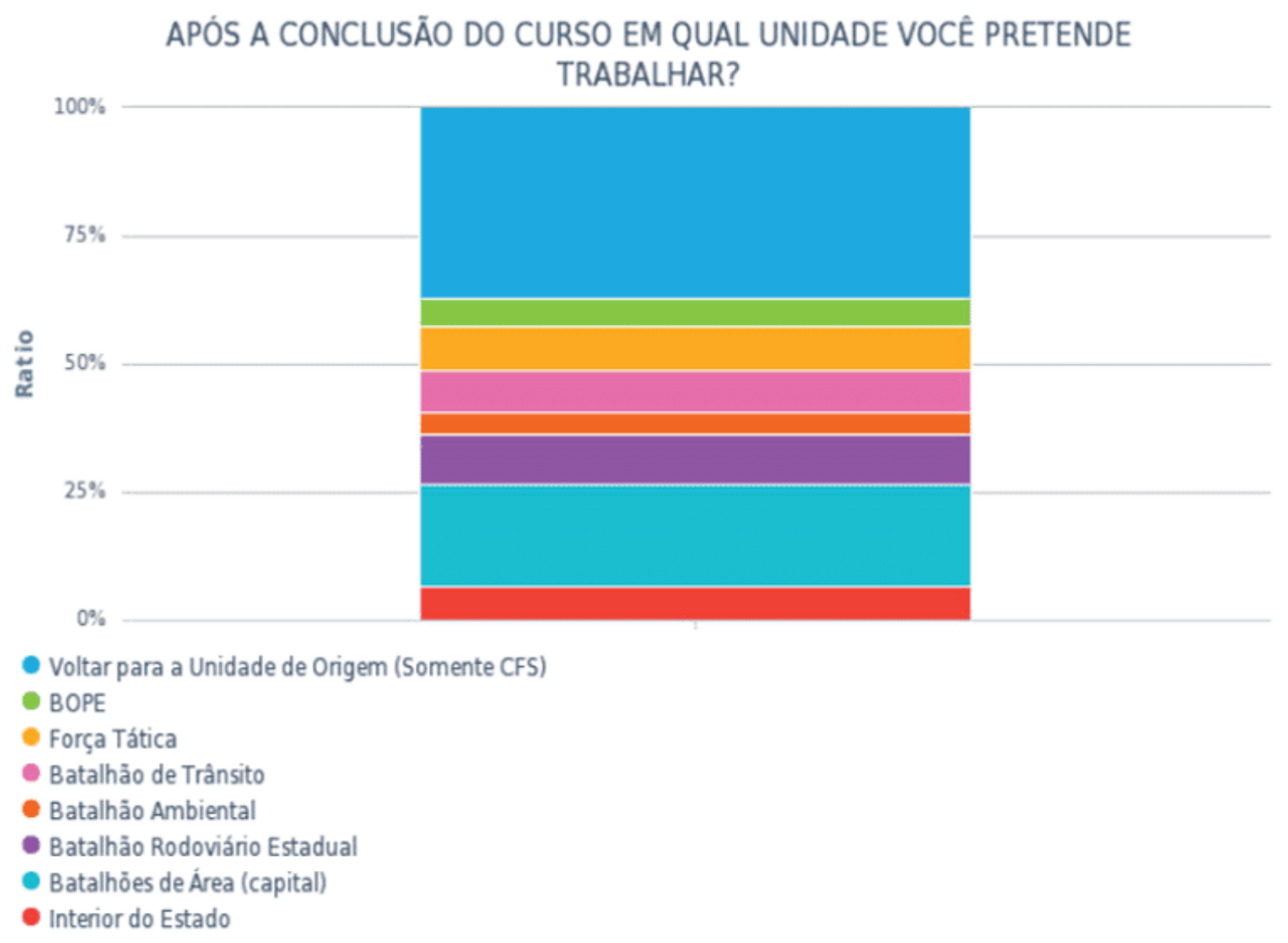

Fonte: Do autor

Em relação a escolha ficou bastante dividido, com exceção dos alunos do curso de sargentos que geralmente voltam para as Unidades de origem, que são 230 equivale aos $37 \%$ os demais fragmentados na maioria dos soldados querem permanecer na capital, 123 equivale a 19,8\% segundo o batalhão rodoviário Estadual com 60 equivale a 9,7\% seguido do batalhão de Força Tática com 53 equivale a 8,5\%, o batalhão de 
trânsito com 50 voluntários equivale a 8,1\% para o interior do Estado 41 equivale a 6,6\%, batalhão ambiental 28 equivale a 4,5\% e por último o BOPE, 36 corajosos voluntários equivale a $5,8 \%$ do universo de 622 alunos dos cursos de soldado e sargentos de 2019.

\section{CONSIDERAÇÕES FINAIS}

Levando em consideração a cobrança de curso superior para o ingresso na Polícia Militar do Amapá ser recente o Centro de Formação e Aperfeiçoamento, ainda não se adequou com a abordagem de ensino superior, devido ter sido sempre focado no ensino tecnicista, enquanto que a abordagem de um curso superior, requer reflexões, discussões, construir conhecimentos, com descobertas cientificas facilitando aos alunos uma construção reflexiva, próxima aos desafios da atividades profissionais de Segurança Pública. Pois, a "resolução de problemas é indicada para a formação profissional, pois propicia a transferência de aprendizagem, ao fazer com que o estudante enfrente novas situações, dotando capacidade para resolver problemas" (CORDEIRO, 2005)

E analisando o processo ensino e aprendizagem do Centro de Formação e Aperfeiçoamento, apresentou algumas falhas, conforme os dados apresentados, através das respostas dos alunos do curso de formação de soldado e de formação de sargentos, que deu credibilidade na pesquisa por vários motivos, pelo público alvo, com características distintas, um com experiências profissionais, no caso dos alunos a sargentos, e outro alunos vindos do mundo civil, sem experiências policiais, que fizeram concurso para o cargo de soldado na Polícia Militar do Amapá. Porém, nas mesmas situações de alunos, com essa amostra que proporcionou uma margem de erro de $4 \%$ com confiabilidade de $99 \%$ do presente trabalho, se torna uma pesquisa relevante para o ensino profissional na Instituição.

Segundo as respostas do público pesquisado, em relação aos cursos de soldado ter uma carga horária elevada de 1.309 (mil trezentos e nove) horas/a, o curso de formação de sargento de 996 (novecentos e noventa e seis) horas/a conforme o planejamento dos respectivos cursos em relação ao curso especial de sargento são 
de 300 (trezentas) horas-aulas, 50\% afirmaram que o período de curso é suficiente, equivale a 311 (trezentos e onze) e $38,3 \%$ acham que poderia ser reduzida, equivale a 238 (duzentos e trinta e oito) alunos, levando em consideração outros fatores, como exemplo as substituições das disciplinas de conhecimentos Gerais serem substituídas pelas da área da Segurança Pública, 90,2\% equivale a 561 (quinhentos e sessenta e um) alunos gostariam que as disciplinas fossem substituídas.

Outra situação observada que a Portaria ํo 007/2017-DGE, publicado no Boletim Geral 끈 024, de 05 de fevereiro de 2019 que relacionam os cursos e as carga-horárias detectou que eram menores que a apresentadas no planejamento de ensino. Outro fator observado foi em relação a carga horária dos sargentos que exercem as mesmas atribuições, a uma discrepância em relação a carga horária.

Também, constatou que a frequência mediana de 12(doze) faltas de professores mensalmente,62,3\% equivalente a 388 (trezentos e oitenta e oito) alunos afirmaram que já ficaram sem aula pelo menos de 02 a 04 aulas, enquanto $26,2 \%$ equivalente a 163 (cento e sessenta e três) afirmaram que ficaram sem aulas acima de 05 a 08 aulas.

Em relação a plataforma disponibilizada poderia ser melhor aproveitada com mais disciplinas ensinadas pela plataforma on line, 36,8\% afirmaram que de 01 a 05 disciplinas poderiam ser ensinadas pela plataforma, equivale a 229 (duzentos e vinte e nove) alunos, 30,4\% afirmaram de 06 a 10 disciplinas que poderiam ser utilizadas na plataforma do CFA, equivale a 189 (cento e oitenta e nove), acima de 10 disciplinas foram $24,9 \%$ equivale a 156 (cento e cinquenta e seis).

Em relação a disciplina de abordagem $78,6 \%$ dos pesquisas foram a favor dos estágios nas unidades operacionais para assimilar melhor na prática, com vivência em situações reais fundamental para toda profissão, que raramente vão ter situações em região rural, que utilizaram 120 (cento e vinte) horas/a no Estágio Operacional Policial de Adaptação na Selva (EOPAS) já que existem os batalhões especializados, que esse tempo fosse distribuídos na disciplina de abordagem nos batalhões para vivencia policial, e que fosse realizados também estágios nas diversas especialidade, 
como ambiental, trânsito, rural, Força Tática e Batalhão de Operações Especiais para os futuros integrantes.

Por fim, o não favorecimento de estágios, além dos muros do centro de ensino, sem contemplar atividades extras com contato e intercâmbio com todos os órgãos de Segurança Pública, comunidades, ONGs, instituições de ensino, além, que o CFA ainda não conseguiu junto às Secretarias e o Conselho de Educação Estadual para o credenciamento da instituição o reconhecimento dos cursos ofertados, situações previstas na Matriz Curricular Nacional.

Concluindo que a presente pesquisa possa ser matéria de discussão a nível estratégico da Instituição para tomada de decisão com a Diretoria de Ensino e o CFA para melhor planejamento educacional em consonância com a MCN dando ênfase na pesquisa, produção do conhecimento, com isso, elevando o nível qualificação dos integrantes da Polícia Militar do Amapá em todos os níveis de formação do soldado aos oficiais que conduziram a Instituição para melhor servir à sociedade.

\section{REFERÊNCIAS}

AMAPÁ. LEI COMPLEMENTAR № 0084, de 07 de Abril de 2014, que dispõe sobre o Estatuto dos Militares do Estado do Amapá em consonância com as disposições do art. 42, § 1丷, art. 142, § $3^{\circ}$, inciso X da Constituição Federal e dá outras providencias. Publicada no Diário Oficial do Estado № 5688, de 07.04.2014. Disponível em: http://www.al.ap.gov.br/<acesso em 29 de dezembro de 2019>

AMAPÁ. Polícia Militar do., criação do Batalhão de Operações Especiais. Disponível em: https://pm.portal.ap.gov.br/conteudo/batalhoes/bope<acesso em 12 de dezembro de 2019>

BENAVENTE. R., Delinquência juvenil: Da disfunção social à psicopatologia. Análise Psicológica, p. 637-645, 2002.

BRASIL. [Constituição (1988)]. Constituição da República Federativa do Brasil de 1988. Brasília, DF: Presidência da República, [2016]. Disponível em: 
http://www.planalto.gov.br/ccovil_03/Constituicao/Constituicao.htm<acesso em 29 de dezembro de 2019>

CORDEIRO, B. M. P.; SILVA, S. S., Direitos Humanos: referencial prático para docentes do Ensino Policial. 2. ed. Brasília: CICV, 2005.

FARIA, D.G.R. ASPECTOS TEÓRICOS DO CAMPO DE ESTUDOS SOBRE SEGURANÇA PÚBLICA, Instituto de Psicologia da Universidade de São Paulo/IPUSP, São Paulo, p.1-10, 2006.

GONZALEZ. J., história da Educação no Brasil, 2019. 1 vídeo (45min). Publicado pelo canal concursos para professores. Disponível em: https://www.youtube.com/watch?v=Rx|QvUqsjL<acesso em 29 de dezembro de 2019>

INGOLD, T., Da transmissão de representações à educação da atenção Educação, vol. 33, núm. 1, Pontifícia Universidade Católica do Rio Grande do Sul, Porto Alegre, pp. 6-25, 2010.

JORGE-BIROL, A. P., Políticas públicas de prevenção da violência e a prevenção vitimária. Âmbito Jurídico, Rio Grande, n. 42, jun. 2007, Disponível em: http://www.ambitojuridico.com.br/site/index.php?n_link=revista_artigos_leitura\&artigo _id=1802>acesso 21de dezembro de 2019>

\section{LAZZARINI, A., A SEGURANÇA PÚBLICA E O APERFEIÇOAMENTO DA POLICIA} NO BRASIL. Criminalidade e violência. Rio de Janeiro, v. I, p.25-85, abr./jun. 1991.

LIMA, F. L. da S. de; PEREIRA, L. da C., Territórios, sujeitos e força policial: pontos sobre a história da Policia Militar do Amapá, IESP, Belém, 2014.

MELLO, C. D. de; TURMENA. L., BASES TEÓRICAS E CONCEITUAIS DA PEDAGOGIA DAS COMPETÊNCIAS: ESTUDO SEGUNDO PHILIPPE PERRENOUDO, Adjunto/Revista Pedagógica da EASA, Paraná, p.91-96, 2018. 
MENDONÇA, L.T.R., ESTUDO DO NÍVEL DE ESTRESSE NA POLÍCIA MILITAR DO AMAPÁ: CONFLITOS E SOLUÇÕES. 2014. 141 f. Tese (Doutorado em Ciências Policiais de Segurança e Ordem Pública) - Academia de Polícia do Barro Branco, Polícia Militar do Estado de São Paulo, São Paulo. 2014.

MENDONÇA, L.T.R., 0 estresse na atividade de rádio patrulha em policiais militares do Amapá. Revista Eletrônica Acervo Saúde/ Electronic Journal Collection Health EAS, vol. Sup. 8, p. 567/572, 2017.

MENEZES, E.T. de; SANTOS, T. H. dos., Verbete educação profissional. Dicionário Interativo da Educação Brasileira-Educabrasil. São Paulo, Midiamix, 2001. Disponível em: <https://www.educabrasil.com.br/educacaoprofissional/>. Acesso em: 15 de dez. 2019.

PASSOS, A. da SILVEIRA et al., Matriz curricular nacional para ações formativas dos profissionais da área de segurança pública. Secretaria Nacional de Segurança Pública, Brasília, p.362, 2014.

POLICIA NO BRASIL. Criminalidade e violência. Rio de Janeiro, v. I, p.25-85, abr./jun. 1991.

ROLIM, M. F., A síndrome da Rainha Vermelha: policiamento e segurança pública no Século XXI, Zahar Ed.; Oxford, Inglaterra: University of Oxford, Centre for Brazilian Studies, Rio de Janeiro, Sindicato Nacional dos Editores de Livros, p.1-311, 2006.

\section{APÊNDICE - REFERÊNCIAS DE NOTA DE RODAPÉ}

2. wwwsurvio.com

3. Disponível: http://cfa-pmap.com.br/ead/

4. Disponível em: https://www.youtube.com/watch?v=RxIQvUqsjLc<acesso em 27 de dezembro de 2019> 
5. Propedêutica é uma palavra de origem grega que se refere ao ensino. Pode ser um curso ou parte de um curso de introdução de disciplinas nas áreas de artes, ciências, educação e outras. Pode ser entendida como um curso introdutório que supre a necessidade básica de conhecimento em um assunto, mas não dá capacidades profissionais.

6. Decreto-Lei ํo 4.244 de 9 de Abril de 1942 disponível em: http://www.histedbr.fe.unicamp.br/navegando/fontes_escritas/5_Gov_Vargas/decreto -lei\%204.244-1942\%20reforma\%20capanema-ensino\%20secund\%E1rio.htm<aceso em 22 de dezembro de 2019>

7. G1 Amapá, disponível em:https://g1.globo.com/ap/amapa/noticia/concurso-parasoldado-da-pm-do-amapa-tem-media-de-48-candidatos-por-vaga.ghtml<acesso em 22 de dezembro de 2019>

8. É um instrumento de patrulhamento em que 02 (dois) policiais militares atuam no processo motorizado, em veículo de quatro rodas, realizando o patrulhamento preventivo, atendimento de ocorrências, a partir de iniciativa de intervenção e de pedidos formulados diretamente pela comunidade ou mediante empenho pelo sistema de teleatendimento de emergência policial. https://www.policiamilitar.mg.gov.br/portal$\mathrm{pm} /$ portalinstitucional $/$ conteudo .action $?$ conteudo $=692 \&$ tipoConteudo $=$ subP $<$ acesso em 14 de dezembro de 2019>

9. Lei no 13.060/14 não se referiu expressamente a "armas não letais", preferindo a denominação "instrumentos de menor potencial ofensivo", que devem ser entendidos, de acordo com o disposto no seu art. $4^{\circ}$, como aqueles projetados especificamente para, com baixa probabilidade de causar mortes ou lesões permanentes, conter, debilitar ou incapacitar temporariamente pessoas. Disponível em: http://www.cartaforense.com.br/conteudo/artigos/uso-de-armas-nao-letais-pelasforcas-policiais/15054<acesso em 19 de Dezembro de 2019>

10. Disponível em: https://www.recantodasletras.com.br/cronicas/6717070<acesso em 21 de Dezembro de 2019> 
11. É o ato de uma Guarnição Policial Militar aproximar-se e interpelar pessoa que apresente conduta suspeita, a fim de identificá-la e/ou proceder à busca, de cuja ação poderá resultar a prisão, a apreensão de pessoa ou coisa ou uma simples advertência ou orientação. É uma das principais atividades realizadas pelos Policiais Militares em seu trabalho diário, visando a prevenção de crimes e contravenções. Disponível em: https://robertoparentoni.jusbrasil.com.br/artigos/121939878/abordagens-policiaisdireitos-deveres-e-dicas-de-comportamento<acesso em 21 de Dezembro de 2019>

12. São ações formativas de segurança pública devem ser entendidas como um processo aberto, complexo e diversificado que reflete, desafia e provoca transformações na concepção e implementação das políticas públicas de segurança, contribuindo para a construção de novos paradigmas culturais e estruturais. (MATRIZ CURRICULAR NACIONAL, 2014, p.38)

13. Ordem pública não é de todo para parte, mas de "efeito para causa", concluindo que a "segurança pública é o conjunto de processos políticos e jurídicos destinados a garantir a ordem pública na convivência de homens em sociedade, segundo Neto (1987, p. 152 apud LAZZARINI, 1991, p.26).

14. A prevenção primária ressalta a educação, a habitação, o trabalho, a inserção do homem no meio social. A qualidade de vida, como elementos essenciais para a prevenção do crime, elementos estes que operam sempre a longo e médio prazo e se dirigem a todos os cidadãos. (JORGE-BIROL, 2007)

15. Regime de trabalho em turno: $12 \mathrm{~h}$ de serviço por $24 \mathrm{~h}$ de folga, $12 \mathrm{~h}$ de serviço e $72 \mathrm{~h}$ de folga

Enviado: Dezembro, 2019.

Aprovado: Março, 2020. 